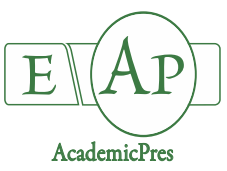

Katsenios N et al. (2020)

Notulae Botanicae Horti Agrobotanici Cluj-Napoca 48(3):1398-1412

DOI: $10.15835 /$ nbha48311989

Research Article

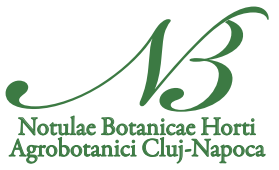

\title{
Influence of pulsed electromagnetic field as a pre-sowing treatment on germination, plant growth and yield of broad beans
}

\author{
Nikolaos KATSENIOS ${ }^{1 *}$, Panagiotis SPARANGIS ${ }^{2}$, \\ Ioanna $\mathrm{KAKABOUKI}^{1}$, Aspasia EFTHIMIADOU ${ }^{2}$
}

\footnotetext{
${ }^{1}$ Agricultural University of Athens, Department of Crop Science, Laboratory of Agronomy, 75 Iera Odos Str., 11855 Athens, Greece; nkatsenios@gmail.com (*corresponding author);i.kakabouki@gmail.com

${ }^{2}$ Institute of Soil and Water Resources, Department of Soil Science of Athens, Hellenic Agricultural Organization - Demeter, Sofokli

Venizelou 1, Lycovrissi, 14123,Attica, Greece; pansparangis@gmail.com; sissyefthimiadou@gmail.com
}

\begin{abstract}
Magnetic field is a variable abiotic factor, like temperature, air, soil and water that interacts with the living organisms. The use of different types of magnetic field at many different plant species is increasing and the results are promising. A two-year field experiment was established following a completely randomized design, to investigate the effect of pre-sowing magnetic field treatment for $0,15,30$ and $45 \mathrm{~min}$ on three broad bean varieties. The obtained results showed that the treatment of seeds with pulsed electromagnetic field increased germination percentage, chlorophyll content, leaf area, photosynthetic rate, transpiration rate, stomatal conductance and dry weight. In general, the exposure of seeds for $15 \mathrm{~min}$, gave the highest values compared to the control treatments for the three varieties used. A very interesting result is the fact that although there was an influence of the exposure of magnetic field on the dry weight of the plants, there was not a positive or a negative influence on the seed yield for both years. This means that magnetic field enhanced the vegetative development of the broad beans, but it had no effect on the reproductive development. The results indicate that magnetic field can be used in the cases that the productive direction of the cultivation of broad beans is for livestock forage and silage, as the pre-sowing treatment of seeds had a positive effect on plant dry weight.
\end{abstract}

Keywords: broad beans; forage; pre-sowing; pulsed electromagnetic field; seed priming

\section{Introduction}

Magnetic field and its effect on plant growth and quality characteristics is a new field of research that is increasingly gaining the interest of researchers in agronomic science. A great deal of research has been carried out in the last decades investigating how magnetic field impacts some very important plant and animal functions. Germination and early stages of plant growth are two stages in plant's life cycle that define its general growth and the quantity and quality of the yield. Indeed, it is known that in order to ensure the best results in case of yield, it is of major concern the crop seedlings to be established in the best possible way in the field, even under non-optimal environmental and soil conditions (temperature, salinity, relative humidity, etc.) and thus research targets on finding methods to optimize the early plant growth characteristics (Ashraf and Foolad, 
2005). These methods are called to be cooperatively easy to implement and environmentally friendly while at the same time aiming at lowering the production cost (Vashisth and Nagarajan, 2010). The magnetic field, just like temperature, air, soil and water, is considered as one of the abiotic factors of each location that all living organisms interact with. However, for many years, the earth's magnetic field was considered as a constant parameter of the environment and it was not taken into account in the studies on plants from time to time. According to Aladjadjiyan (2012), plants' sensitivity to the effect of natural factors was the result of the process of evolution, as these factors are elements of their natural environment. In recent years, the way magnetic fields and living systems interact gained interest and are being examined in detail. The interest of the research that has been carried out focuses both on human structures capable of producing different forms of magnetic fields (Soja et al., 2003), on the earth's natural magnetic field (Aksyonov et al., 2001; Es'kov and Rodionov, 2010) and how this can affect the biological functions of plants.

The magnetic field plays an essential role in how it affects plants; its type, the duration of the exposure as well as its intensity, are all crucial parameters that contribute to magnetics field variability. There are various types of a magnetic field (pulsed electromagnetic, static, electromagnetic) that have found applications in agricultural research on plants (Aguilar et al., 2009; Bilalis et al., 2012a). The magnetic field can be used with different combinations of intensity and duration of exposure and give different results (Leelapriya et al., 2003; Bilalis et al., 2012b). In earlier studies, applications with pulsed, alternating and static magnetic fields have been performed, with exposure times ranging from seconds (Muszyński et al., 2009) to hours (Martinez et al., 2009).

Applying magnetic fields of a specific range to improve crop production is a non-toxic, immediately useful and inexpensive method that stimulates seed viability, germination and growth (Radhakrishnan and Kumari, 2012). Results from various studies conducted in recent decades show that applications of different magnetic field frequencies aid the plant development of cotton (Leelapriya et al., 2003) and maize (Vashisth and Joshi, 2017). It also appeared to have a positive effect on tomato plants that the use of pre-sowing MF treatment produced better results in case of yield and growth (De Souza et al., 2006), onions that an increase of the chlorophyll and protein content in a certain variety was observed (Novitsky et al., 2001), rice where the use of MF enhanced the germination of the seeds (Carbonell et al., 2000), soy in which the use of pulsed magnetic field increased not only the growth and yield but also all the productivity in general (Radhakrishnan and Kumari, 2012). In particular, there are many studies, which conclude that the use of magnetic field affects positively the germination rates of seeds (Carbonell et al., 2000; Aladjadjiyan and Ylieva, 2003; Podlesny et al., 2004; Bilalis et al., 2012b; Katsenios et al., 2016). For instance, Podlesny and his colleagues (2004), confirmed the positive effect of the magnetic field on germination and emergence on two varieties of broad beans while it also presented better results to final seed yield after a pre-sowing application.

Moreover, the magnetic field treatment produced interesting results in case of the action of some hydrolytic enzymes. For instance, Bhardwaj et al. (2012) noticed an increase in the activity of $\beta$-amylase in cucumber seeds that were exposed to magnetic field treatment. Also, Katsenios et al. (2016) exposed durum wheat seeds to magnetic field and found that this treatment affected $\alpha$-amylase activity that could explain the increase of the germination rates. The application of magnetic fields to achieve goals like the above could be particularly effective in the efforts of researchers to improve plant growth with environmentally friendly techniques (Bilalis et al., 2013).

The aim of this study was to investigate the effect of four different times of exposure $(0,15,30$ and 45 min) at pulsed electromagnetic field on three cultivars of broad beans ('Negreta', 'Smeralda' and 'Super Aquadulce'), as a pre-sowing treatment. A wide range of measurements (germination, leaf area, chlorophyll content, physiology measurements, dry weight, yield) has been conducted in order to cover all possible positive effects of this environmentally friendly method. 


\section{Materials and Methods}

\section{Study site and plant material}

A field experiment was established at the Agricultural University of Athens (Greece) for two cultivation periods (2009/10 and 2010/11). Three broad bean varieties were used, 'Negreta', 'Smeralda' and 'Super Aquadulce' (Geoponiki S.A.). 'Negreta' is a variety with early maturity, with large green pods $25-26 \mathrm{~cm}$ that include 6-7 large beans. 'Smeralda' is a variety with high productivity, large plants up to $80-90 \mathrm{~cm}$, with large green pods up to $35 \mathrm{~cm}$ that include 8-9 large beans. 'Super Aquadulce' is a vigorous variety with large green pods 25-30 cm that include 5-7 large beans.

\section{Experimental design}

The experiment followed a completely randomized design, with four treatments $(0,15,30$ and $45 \mathrm{~min}$ of exposure at pulsed electromagnetic field) and three varieties. Non-treated seeds ( 0 minutes $)$ were used as control, while seeds treated before sowing for 15, 30 and 45 minutes were the treatments 15, 30 and 45 respectively. The experiment had three replications and was conducted for two cultivation periods. Every replication was consisted of an area of $3 \mathrm{~m}^{2}$. The number of seeds used was 30 for all varieties at every plot.

The pre-sowing treatment of seeds was conducted with PAPIMI device, which is a pulsed electromagnetic field (PEMF) generator (PAPIMI model 600; Pulse Dynamics, Athens, Greece. Manufacturer characteristics: $35-80 \mathrm{~J} /$ pulse energy, $1 \times 10^{-6} \mathrm{~s}$ wave duration, $35-80 \times 106 \mathrm{~W}$ wave power, amplitude of the order of $12.5 \mathrm{mT}$, rise time $0.1 \mathrm{~ms}$, fall time $10 \mathrm{~ms}$, repetitive frequency of $3 \mathrm{~Hz}$ ).

\section{Measurements and observations}

Germination (\%) measurement took place 10, 15 and 30 DAS, by measuring the number of plants per row. The chlorophyll $\left(\mu \mathrm{g} \mathrm{cm}^{-2}\right)$ measurement has been conducted with a portable chlorophyll meter (SPAD) and then the values have been converted to $\mu \mathrm{g} \mathrm{cm}^{-2}$ using a calibration curve that has been created under laboratory determination of chlorophyll (Lichtenthler and Wellburn, 1983). The measurements took place 60, 90 and 120 DAS. The physiology measurements of photosynthetic rate $\left(\mu \mathrm{mol} \mathrm{CO} \mathrm{C}^{-2} \mathrm{~s}^{-1}\right)$, transpiration rate $\left(\mathrm{mmol} \mathrm{H}_{2} \mathrm{O} \mathrm{m}^{-2} \mathrm{~s}^{-1}\right)$ and stomatal conductance $\left(\mathrm{mol} \mathrm{m}^{-2} \mathrm{~s}^{-1}\right)$ took place 60,90 and $120 \mathrm{DAS}$, using an LCi Leaf Chamber Analysis System (ADC, Bioscientific, Hoddesdon, UK). The measurements were taken on fully expanded leaves, during midday hours, under clear sky without clouds. Leaf area $\left(\mathrm{cm}^{2}\right.$ per plant) and stem dry weight (g per plant) were destructive measurements and took place 50, 80 and 110 DAS respectively. Leaf area was measured with an automatic leaf area meter (Delta-T Devices Ltd., Burrwell, Cambridge, UK). Stem dry weight was measured with a precision balance after the samples were oven-dried at $70^{\circ} \mathrm{C}$ for three days in order to measure the weight in grams per plant. Yield $\left(\mathrm{g}\right.$ plant $\left.{ }^{-1}\right)$ took place $150 \mathrm{DAS}$, when all plants seedpods were mature (brown).

\section{Statistical analysis}

The experimental data were analyzed using IBM SPSS software ver. 24 (IBM Corp., Armonk, N.Y., USA). The evaluation of the effect of magnetic field treatments of various durations, the different varieties of broad beans and their interaction, in case of germination, plant growth and physiology measurements, was calculated via two-way analysis of variance (ANOVA). The comparisons of means were calculated using Duncan test at the $5 \%$ level of significance $(\mathrm{p}<0.05)$. 


\section{Results and Discussion}

The effect of pulsed electromagnetic field as a pre-sowing treatment presented positive responses to broad bean germination percentage, leaf area, chlorophyll content, photosynthetic rate, transpiration rate, stomatal conductance and dry weight, while it did not appear to have statistically significant effect to the final seed yield. The interaction between magnetic field and the varieties of broad beans that were tested appeared to be statistically significant in most of the measurements that were performed (Table 1).

Table 1. Analysis of variances (F values)

\begin{tabular}{|c|c|c|c|c|c|c|c|}
\hline & & \multicolumn{3}{|c|}{ Germination (\%) } & \multicolumn{3}{|c|}{ Leaf area $\left(\mathrm{cm}^{2}\right.$ plant $\left.{ }^{-1}\right)$} \\
\hline \multirow{19}{*}{$\begin{array}{l}\text { First } \\
\text { year }\end{array}$} & Days after sowing & 10 DAS & $15 \mathrm{DAS}$ & 30 DAS & $50 \mathrm{DAS}$ & $80 \mathrm{DAS}$ & $110 \mathrm{DAS}$ \\
\hline & Variety & $796,85^{* * *}$ & $1120,89^{* * *}$ & $183,66^{* * *}$ & $192,54^{* * *}$ & $205,68^{* * *}$ & $355,90^{* * *}$ \\
\hline & Magnetic & $23,38^{* * *}$ & $32,94^{* * *}$ & $35,49^{* * *}$ & $88,61^{* * *}$ & $127,76^{* * *}$ & $30,81^{* * *}$ \\
\hline & Variety*Magnetic & $8,18^{* * *}$ & $6,15^{* *}$ & $3,53^{*}$ & $5,67^{* *}$ & $12,83^{* * *}$ & $10,72^{* * *}$ \\
\hline & & \multicolumn{3}{|c|}{ Chlorophyll content $\left(\mu \mathrm{g} \mathrm{cm}^{-2}\right)$} & \multicolumn{3}{|c|}{ Photosynthetic rate $\left(\mu \mathrm{mol} \mathrm{CO} 2 \mathrm{~m}^{-2} \mathrm{~s}^{-1}\right)$} \\
\hline & Days after sowing & 60 DAS & 90 DAS & 120 DAS & 60 DAS & $90 \mathrm{DAS}$ & 120 DAS \\
\hline & Variety & $34,27^{* * *}$ & $51,66^{* * *}$ & $577,94^{* * *}$ & $3,5^{*}$ & $269,40^{* * *}$ & $2,38 \mathrm{~ns}$ \\
\hline & Magnetic & $34,63^{* * *}$ & $43,19^{* * *}$ & $156,74^{* * *}$ & $24,61^{* * *}$ & $94,04^{* * *}$ & $17,43^{* * *}$ \\
\hline & Variety* Magnetic & $4,79^{* *}$ & $10,65^{* * *}$ & $8,29^{* * *}$ & $5,41^{* *}$ & $37,94^{* * *}$ & $3,31^{*}$ \\
\hline & & \multicolumn{3}{|c|}{ Transpiration rate $\left(\mathrm{mmol} \mathrm{H}_{2} \mathrm{O} \mathrm{m}^{-2} \mathrm{~s}^{-1}\right)$} & \multicolumn{3}{|c|}{ Stomatal conductance $\left(\mathrm{mol} \mathrm{m}^{-2} \mathrm{~s}^{-1}\right)$} \\
\hline & Days after sowing & $6 \mathrm{DAS}$ & $90 \mathrm{DAS}$ & $120 \mathrm{DAS}$ & $60 \mathrm{DAS}$ & $90 \mathrm{DAS}$ & $120 \mathrm{DAS}$ \\
\hline & Variety & $34,27^{* * *}$ & $51,66^{* * *}$ & $577,94^{* * *}$ & $14,58^{* * *}$ & $8,71^{* *}$ & $6,82^{* *}$ \\
\hline & Magnetic & $34,63^{* * *}$ & $43,19^{* * *}$ & $156,74^{* * *}$ & $34,33^{* * *}$ & $12,80^{* * *}$ & $4,39^{*}$ \\
\hline & Variety*Magnetic & $4,79^{* *}$ & $10,65^{* * *}$ & $8,29^{* * *}$ & $6,83^{* * *}$ & $2,15 \mathrm{~ns}$ & $2,22 \mathrm{~ns}$ \\
\hline & & \multicolumn{3}{|c|}{ Dry weight $\left(\right.$ g plant $\left.^{-1}\right)$} & \multicolumn{3}{|c|}{ Yield (g plant $\left.{ }^{-1}\right)$} \\
\hline & Days after sowing & $50 \mathrm{DAS}$ & $80 \mathrm{DAS}$ & $110 \mathrm{DAS}$ & \multicolumn{3}{|c|}{$150 \mathrm{DAS}$} \\
\hline & Variety & $61,49^{* * *}$ & $324,48^{* * *}$ & $98,64^{* * *}$ & \multicolumn{3}{|c|}{$345,94^{* * *}$} \\
\hline & Magnetic & $42,97^{* * *}$ & $132,09^{* * *}$ & $139,33^{* * *}$ & \multicolumn{3}{|c|}{$0,58 \mathrm{~ns}$} \\
\hline & Variety* Magnetic & $0,96 \mathrm{~ns}$ & $4,23^{* *}$ & $11,60^{* * *}$ & \multicolumn{3}{|c|}{$0,8 \operatorname{lns}$} \\
\hline \multirow{20}{*}{$\begin{array}{c}\text { Second } \\
\text { year }\end{array}$} & & \multicolumn{3}{|c|}{ Germination (\%) } & \multicolumn{3}{|c|}{ Leaf area $\left(\mathrm{cm}^{2}\right.$ plant $\left.^{-1}\right)$} \\
\hline & Days after sowing & $10 \mathrm{DAS}$ & $15 \mathrm{DAS}$ & $30 \mathrm{DAS}$ & $50 \mathrm{DAS}$ & $80 \mathrm{DAS}$ & $110 \mathrm{DAS}$ \\
\hline & Variety & $883,98^{* * *}$ & $400,50^{* * *}$ & $99,09^{* * *}$ & $394,42^{* * *}$ & $68,91^{* * *}$ & $2357,42^{* * *}$ \\
\hline & Magnetic & $33,69^{* * *}$ & $14,57^{* * *}$ & $12,35^{* * *}$ & $97,34^{* * *}$ & $9,95^{* * *}$ & $76,14^{* * *}$ \\
\hline & Variety*Magnetic & $7,52^{* * *}$ & $3,36^{*}$ & $2,63^{*}$ & $5,00^{* *}$ & $1,82 \mathrm{~ns}$ & $17,02^{* * *}$ \\
\hline & & \multicolumn{3}{|c|}{ Chlorophyll content $\left(\mu \mathrm{g} \mathrm{cm}^{-2}\right)$} & \multicolumn{3}{|c|}{ Photosynthetic rate $\left(\mu \mathrm{mol} \mathrm{CO} 2 \mathrm{~m}^{-2} \mathrm{~s}^{-1}\right)$} \\
\hline & Days after sowing & 60 DAS & $90 \mathrm{DAS}$ & $120 \mathrm{DAS}$ & 60 DAS & $90 \mathrm{DAS}$ & $120 \mathrm{DAS}$ \\
\hline & Variety & $99,02^{* * *}$ & $139,84^{* * *}$ & $378,85^{* * *}$ & $29,28^{* * *}$ & $269,40^{* * *}$ & $107,90^{* * *}$ \\
\hline & Magnetic & $72,90^{* * *}$ & $54,16^{* * *}$ & $65,52^{* * *}$ & $51,138^{* * *}$ & $94,04^{* * *}$ & $118,41^{* * *}$ \\
\hline & Variety*Magnetic & $7,17^{* * *}$ & $7,02^{* * *}$ & $7,88^{* * *}$ & $1,5 \operatorname{lns}$ & $37,94^{* * *}$ & $24,29^{* * *}$ \\
\hline & & \multicolumn{3}{|c|}{ Transpiration rate $\left(\mathrm{mmol} \mathrm{H}_{2} \mathrm{O} \mathrm{m}^{-2} \mathrm{~s}^{-1}\right)$} & \multicolumn{3}{|c|}{ Stomatal conductance $\left(\mathrm{mol} \mathrm{m}^{-2} \mathrm{~s}^{-1}\right)$} \\
\hline & Days after sowing & $60 \mathrm{DAS}$ & 90 DAS & $120 \mathrm{DAS}$ & $60 \mathrm{DAS}$ & $90 \mathrm{DAS}$ & $120 \mathrm{DAS}$ \\
\hline & Variety & $325,13^{* * *}$ & $44,81^{* * *}$ & $483,30^{* * *}$ & $62,11^{* * *}$ & $17,51^{* * *}$ & $77,82^{* * *}$ \\
\hline & Magnetic & $119,20^{* * *}$ & $32,71^{* * *}$ & $107,09^{* * *}$ & $39,41^{* * *}$ & $25,55^{* * *}$ & $49,00^{* * *}$ \\
\hline & Variety*Magnetic & $12,19^{* * *}$ & $14,79^{* * *}$ & $13,91^{* * *}$ & $13,82^{* * *}$ & $0,46 \mathrm{~ns}$ & $3,00^{*}$ \\
\hline & & \multicolumn{3}{|c|}{ Dry weight $\left(\right.$ g plant $\left.^{-1}\right)$} & \multicolumn{3}{|c|}{ Yield $\left(\right.$ g plant $\left.^{-1}\right)$} \\
\hline & Days after sowing & $50 \mathrm{DAS}$ & 80 DAS & $110 \mathrm{DAS}$ & \multicolumn{3}{|c|}{$150 \mathrm{DAS}$} \\
\hline & Variety & $264,53^{* * *}$ & $1149,82^{* * *}$ & $277,42^{* * *}$ & \multicolumn{3}{|c|}{$1097,74^{* * *}$} \\
\hline & Magnetic & $81,42^{* * *}$ & $76,97^{* * *}$ & $116,64^{* * *}$ & \multicolumn{3}{|c|}{$0,28 \mathrm{~ns}$} \\
\hline & Variety*Magnetic & $6,14^{* *}$ & $8,99^{* * *}$ & $17,24^{* * *}$ & & $1,54 \mathrm{~ns}$ & \\
\hline $\begin{array}{l}\mathrm{ns} \\
{ }^{*} \mathrm{Si} \\
{ }^{* *} \mathrm{~S} \\
* * *\end{array}$ & $\begin{array}{l}\text { significant. } \\
\text { cance at } 0.05 \text {. } \\
\text { icance at } 0.01 \text {. } \\
\text { ficance at } 0.001 \text {. }\end{array}$ & & & & & & \\
\hline
\end{tabular}




\section{Germination}

For the germination percentage (\%) measurement an interaction of the variety and magnetic field treatment factors was found in all three measurements (10,15 and 30 DAS), at both years (Table 1). In the first year, statistically significant differences were observed at 'Smeralda' 15 (52, 82 and $92 \%$, for 10, 15 and 30 DAS respectively), 'Smeralda' 30 (49, 84 and $88 \%$, for 10, 15 and 30 DAS respectively) compared to Smeralda $0(36,64$ and $73 \%$, for 10,15 and 30 DAS respectively) and the other treatments with the exception of 'Smeralda' 45, where no statistically significant differences were observed in the last two measurements ( 79 and $86 \%$, for 15 and 30 DAS respectively). Regarding the treatments of the variety 'Negreta', the exposure of 15 minutes gave statistically significant differences compared to the control of 'Negreta' at all measurements, while at the third measurement the germination percentage (81\%) was statistically significant higher even with the other magnetic field treatments. The treatments of variety 'Super Aquadulce' gave lower germination percentage compared to the other varieties. Similarly, the treatment of 15 minutes of magnetic field, gave values statistically significantly higher than the control at all treatments. In general, the magnetic field treatment of 15 minutes duration, presented increased germination percentage than the control treatment with statistically significant differences, in all varieties, in the three measurements (Figure 1).

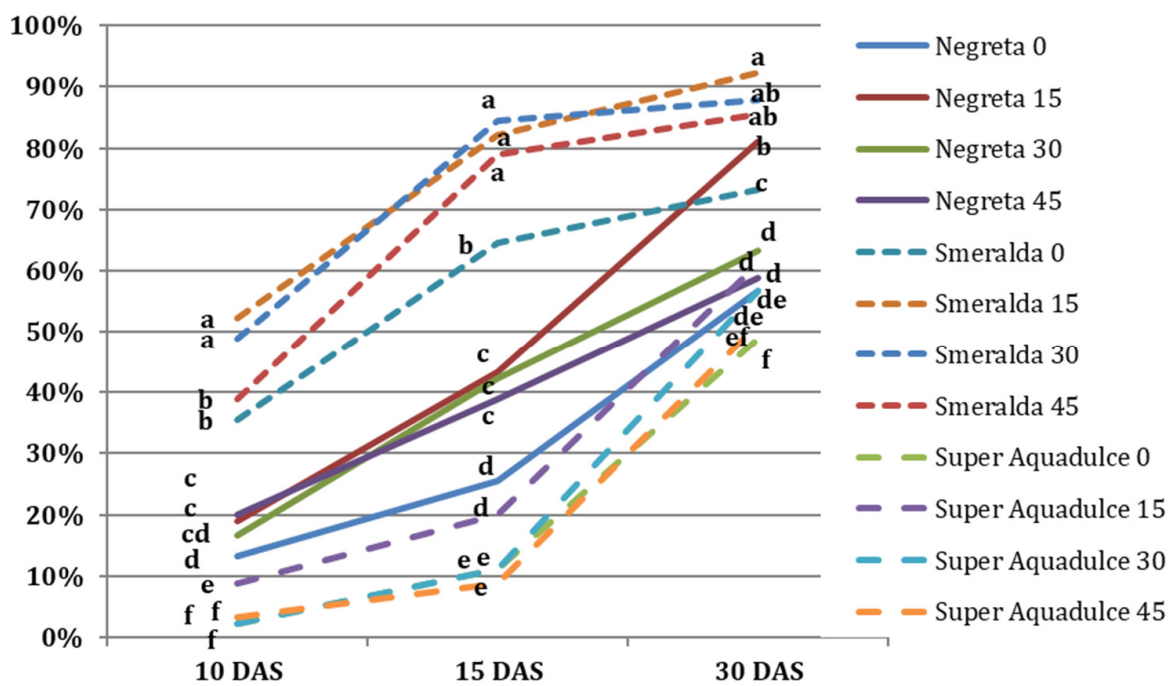

Figure 1. Germination of broad beans in the first year as affected by interaction of variety and magnetic field at 10 days after sowing (DAS), 15 DAS and 30 DAS

For each measurement, means followed by the same lower-case letter (a, b, c, d, e, f) did not differ significantly according to Duncan's multiple range test at $\mathrm{p}<0.05$.

Similar results were observed in the second year of the experimental trials where, just like the first year, the highest germination rates were on the 'Smeralda' 15 (81, 88 and $92 \%$, for 10, 15 and 30 DAS respectively) and 'Smeralda' 30 (78, 84 and 88\%, for 10, 15 and 30 DAS respectively) compared to 'Smeralda' 0 (64, 70 and $78 \%$, for 10, 15 and 30 DAS respectively) and the other MF treatments in all measurements except from Smeralda 45 in the second $(83 \%, 15$ DAS) and third (89\%, 30 DAS) measurement where no statistically significant differences were observed.

Regarding the treatments of the variety 'Negreta', the exposure of 15 minutes $(61,72$ and $81 \%$, for 10 , 15 and 30 DAS respectively) gave statistically significant differences compared to the control of Negreta and the other magnetic field treatments, at all measurements. The treatments of variety 'Super Aquadulce' gave lower germination percentage compared to the other varieties and the treatment of 15 minutes of exposure at magnetic field gave statistically significant differences compared to the control only at the second measurement. 
Overall, in the second year, the germination rates of the MF treatments with duration of 15 minutes of exposure presented better results than most of the treatments and notably, they even reach 92\% ('Smeralda' 15) in the last measurement (Figure 2).

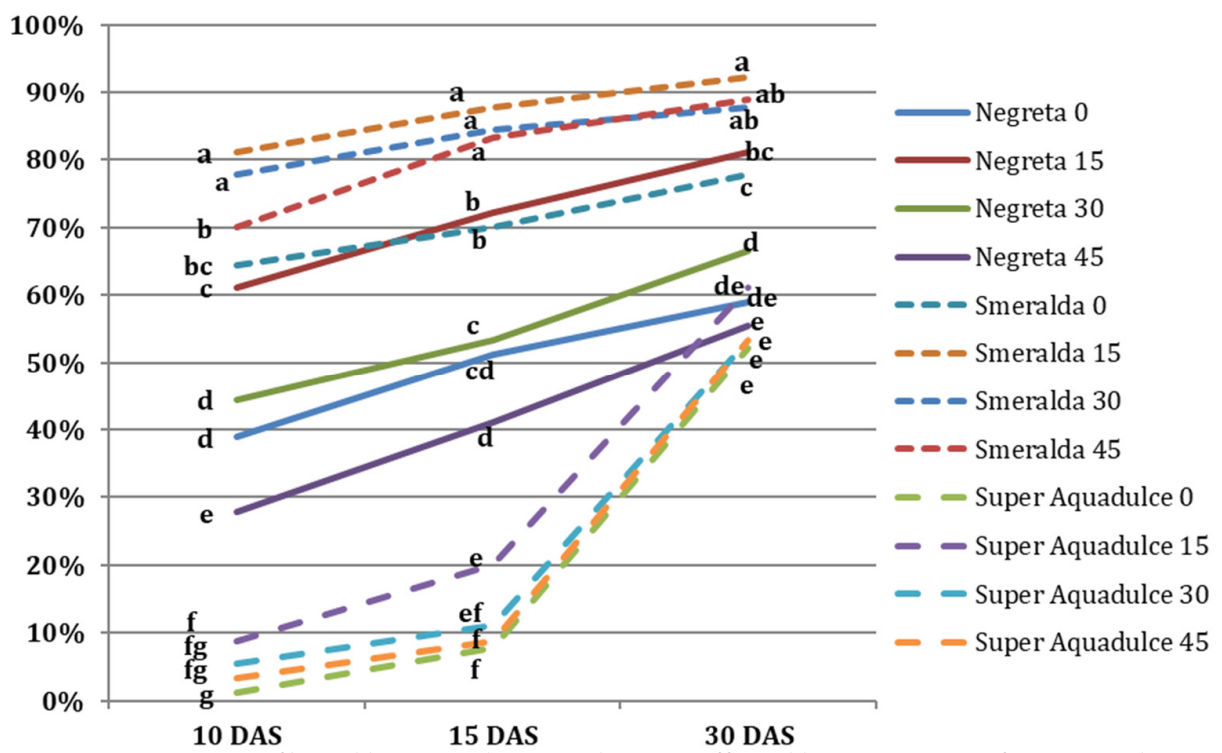

Figure 2. Germination of broad beans in the second year as affected by interaction of variety and magnetic field at 10 days after sowing (DAS), 15 DAS and 30 DAS

For each measurement, means followed by the same lower-case letter (a, b, c, d, e, f) did not differ significantly according to Duncan's multiple range test at $\mathrm{p}<0.05$.

More and more studies have proven that magnetic field tends to have a positive impact on seed germination (Carbonell et al., 2000; Bilalis et al., 2012b; Katsenios et al., 2016). Flórez et al. (2007) accessed the effect of stationary magnetic field exposure on maize seeds to find that the germination rate of the treated seeds was higher than the control. Pulsed magnetic field also has been found to improve the germination of soybeans in various frequencies, with 10 and $100 \mathrm{~Hz}$ of PMS treatments presenting statistically significant results (Radhakrishnan and Kumari, 2013). The findings of this study suggest that magnetic field treatment affects positively the seed germination of broad beans and stands in accordance with other studies conducted on other seeds such as chickpea (Vashisth and Nagarajan, 2008), soybeans (Radhakrishnan and Kumari, 2013) and durum wheat (Katsenios et al., 2016).

\section{Leaf area}

Concerning the leaf area of broad beans $\left(\mathrm{cm}^{2}\right.$ plant $\left.{ }^{-1}\right)$, there was an interaction of variety and magnetic field factors at all the measurements of the first year and the for measurements 50 and 110 DAS for the second year (Table 1). For the first year, 'Smeralda' 15 was the treatment that presented the highest values in all three measurements $\left(255,573\right.$ and $1372 \mathrm{~cm}^{2}$ plant ${ }^{-1}$, for 50, 80 and 110 DAS respectively)with statistically significant differences compared to the 'Smeralda' 0 (223, 436 and $1003 \mathrm{~cm}^{2}$ plant ${ }^{-1}$, for 50, 80 and 110 DAS respectively) treatment. In general, in all varieties, the MF treatments, gave higher values than the control treatment with statistically significant differences, in the three measurements with the exception of 'Negreta' 45 (171,367 and $826 \mathrm{~cm}^{2}$ plant ${ }^{-1}$, for 50,80 and 110 DAS respectively) where no significant differences were observed compared to 'Negreta' 0 (165, 372 and $819 \mathrm{~cm}^{2}$ plant ${ }^{-1}$, for 50, 80 and 110 DAS respectively) (Figure 3). 


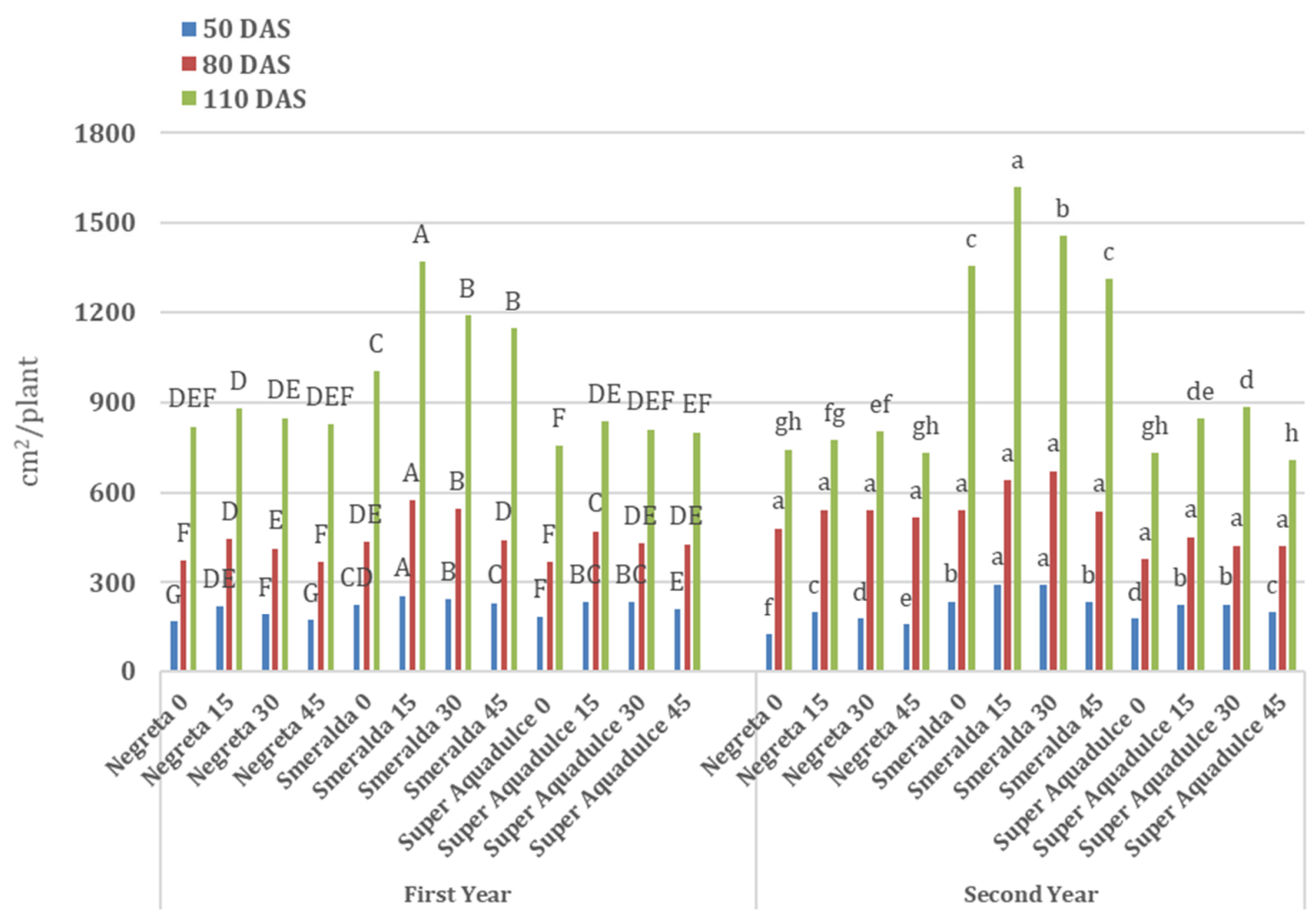

Figure 3. Broad beans Leaf area as affected by variety and magnetic field interaction at 50 days after sowing (DAS), 80 DAS and 110 DAS

For each measurement, means followed by the same capital letter (A, B, C, D, E, F, G) in first year and means followed by the same lower-case letter (a, b, c, d, e, f, g, h) in second year did not differ significantly according to Duncan's multiple range test at $\mathrm{p}<0.05$.

\section{Chlorophyll content}

An interaction of magnetic field and variety factor of broad beans that were tested was found with statistically significant differences, in case of chlorophyll content $\left(\mu \mathrm{g} \mathrm{cm}^{-2}\right)$, for measurements at 60 and 90 days after sowing for the first year and in all three measurements (60,90 and 120 DAS) during the second year. In the first year, high chlorophyll content has been measured at 'Negreta' 15 treatment ( 45.84 and $65.31 \mu \mathrm{g} \mathrm{cm}^{-2}$, for 60 and 90 DAS respectively) with statistically significant differences compared to the 'Negreta' 0 (41.03 and $59.50 \mu \mathrm{g} \mathrm{cm}^{-2}$, for 60 and 90 DAS respectively) treatment, in the first two measurements, while there were no statistically significant differences compared to the MF treatments of Smeralda in the first measurement and 'Negreta' 30 ( $46.09 \mu \mathrm{g} \mathrm{cm}^{-2}, 60 \mathrm{DAS}$ ). In general, the magnetic field treatment of 15 minutes duration, gave higher values than the control treatment with statistically significant differences, in all varieties, in the two first measurements. In the second year, 'Negreta' 15 gave the highest values $\left(48.36,69.62\right.$ and $95.90 \mu \mathrm{g} \mathrm{cm}^{-2}$, for 60, 90 and 120 DAS respectively) with statistically significant differences compared to all other treatments, except 'Negreta' 30 at the first $\left(45.83 \mu \mathrm{g} \mathrm{cm}^{-2}\right)$ and the third measurement $\left(95.79 \mu \mathrm{g} \mathrm{cm}^{-2}\right)$, and Smeralda 15 at the first measurement $\left(45.83 \mu \mathrm{g} \mathrm{cm}^{-2}\right)$. In general, the treatments of magnetic field of varieties 'Smeralda' and 'Super Aquadulce', gave higher values compared to the control treatments, in all measurements with statistically significant differences.

The positive effect of magnetic field treatment at the chlorophyll content has been found from Răcuciu et al. (2006), where germinated seeds of maize exposed at magnetic field. Similarly, at maize plants, magnetic field increased chlorophyll a and b pigments (Javed et al., 2011) (Figure 4). 


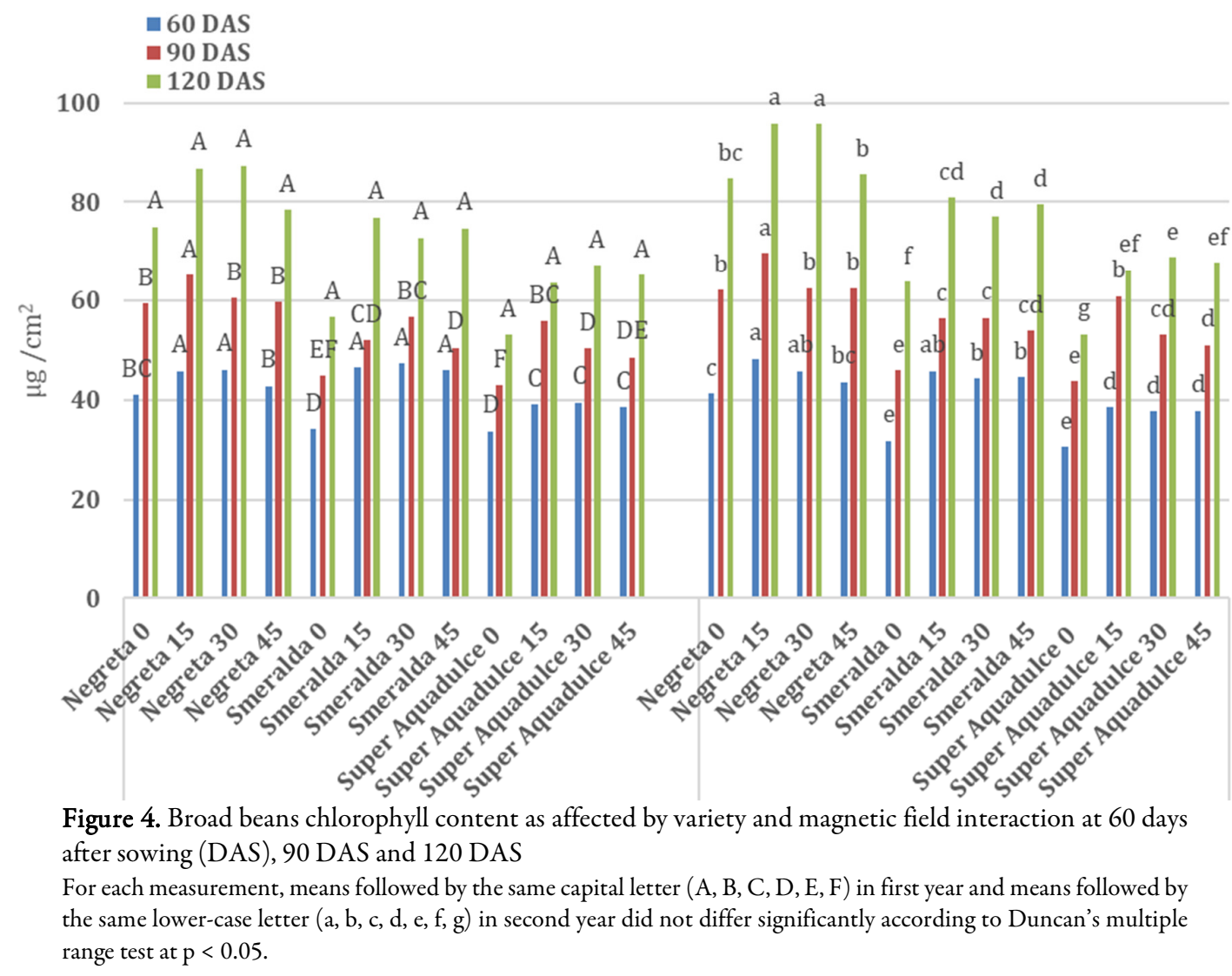

In the second year, on the other hand, 'Smeralda' 15 gave the highest values for the first and third measurement (294 and $1619 \mathrm{~cm}^{2}$ plant ${ }^{-1}$, for 50 and 110 DAS respectively) with statistically significant differences compared to all other treatments. In general, all three varieties when exposed to magnetic field for 45 minutes presented values with no significant differences compared to the control in most of the measurements. De Souza et al. (2006) have come to a conclusion that the pre-sowing magnetic field treatments increase tomato's growth and yield characteristics. In particular, they found that the exposed tomato seeds display an increase in leaf area per plant that reached $22 \%$ in some cases. Increased leaf area has been found at cotton plants derived from seeds treated with magnetic field (Bilalis et al., 2012b). Moreover, Radhakrishnan and Kumari (2012), found that magnetic field treatment gave higher number of leaves at soybean plants, while in another research at soybean plants, magnetic field increased leaf area 100\% (Shine et al., 2011).

\section{Physiology measurements}

Statistically significant differences were also observed at the interaction of magnetic field and variety on photosynthetic rate $\left(\mu \mathrm{mol} \mathrm{CO} \mathrm{Cm}^{-2} \mathrm{~s}^{-1}\right)$, transpiration rate $\left(\mathrm{mmol} \mathrm{H}_{2} \mathrm{O} \mathrm{m}^{-2} \mathrm{~s}^{-1}\right)$ and stomatal conductance (mol $\left.\mathrm{m}^{-2} \mathrm{~s}^{-1}\right)$. For photosynthetic rate, the interactions were statistically significant different in all the measurements of the first year and in the last two measurements (90 and 120 DAS) of the second year. In the first year, 'Negreta' 15 (13.90, 16.43 and $13.86 \mu \mathrm{mol} \mathrm{CO} \mathrm{m}^{-2} \mathrm{~s}^{-1}$, for 60, 90 and $120 \mathrm{DAS}$ respectively) presented high values in all three measurements and statistically significant different from 'Negreta' 0 (10.31, 12.23 and 11.22 $\mu \mathrm{mol} \mathrm{CO} \mathrm{m}^{-2} \mathrm{~s}^{-1}$, for 60,90 and 120 DAS respectively) while there were no statistically significant differences compared to the 'Super Aquadulce' 15 in the first $\left(14.07 \mu \mathrm{mol} \mathrm{CO}_{2} \mathrm{~m}^{-2} \mathrm{~s}^{-1}\right)$ and third measurement $(15.44 \mu \mathrm{mol}$ $\left.\mathrm{CO}_{2} \mathrm{~m}^{-2} \mathrm{~s}^{-1}\right)$. In general, the magnetic field treatment of 15 minutes duration, gave higher values than the control treatment with statistically significant differences, in all varieties, in the three measurements. However magnetic treatment of 45 minutes duration in 'Negreta' and 'Super Aquadulce' gave lower values than those of 
the control in most of the measurements. In the second year, 'Negreta' 15 presented the best photosynthetic rate values second measurement $\left(16.43 \mu \mathrm{mol} \mathrm{CO} \mathrm{m}^{-2} \mathrm{~s}^{-1}\right)$ and statistical different from 'Negreta' $0(12.23 \mu \mathrm{mol}$ $\left.\mathrm{CO}_{2} \mathrm{~m}^{-2} \mathrm{~s}^{-1}, 90 \mathrm{DAS}\right)$. 'Super Aquadulce' 15 presented the highest value in the last measurement (16.33 $\mu \mathrm{mol}$ $\left.\mathrm{CO}_{2} \mathrm{~m}^{-2} \mathrm{~s}^{-1}, 120 \mathrm{DAS}\right)$ with statistical differences to 'Super Aquadulce' $0\left(10.58 \mu \mathrm{mol} \mathrm{CO} \mathrm{C}^{-2} \mathrm{~s}^{-1}, 120 \mathrm{DAS}\right)$. Overall, treatments of 45 minutes duration in all varieties gave lower values than those of the control in most of the measurements.

Transpiration rate values showed an interaction of the variety and magnetic field treatment factors in all three measurements in both years. In the first year were significantly higher for 'Smeralda' 15 in the first two measurements (2.56 and $3.45 \mathrm{mmol} \mathrm{H} \mathrm{O} \mathrm{m}^{-2} \mathrm{~s}^{-1}$ for 60 and 90 DAS) compared to 'Smeralda' 0 (1.53 and 1.67 $\mathrm{mmol} \mathrm{H} \mathrm{O} \mathrm{m}^{-2} \mathrm{~s}^{-1}$ for 60 and $90 \mathrm{DAS}$ ) while there were no significant differences with 'Negreta' 15 (2.51 and $3.39 \mathrm{mmol} \mathrm{H}_{2} \mathrm{O} \mathrm{m}^{-2} \mathrm{~s}^{-1}$ for 60 and $90 \mathrm{DAS}$ ). 'Super Aquadulce' 15 presented the higher value in the last measurement $\left(3.85 \mathrm{mmol} \mathrm{H}_{2} \mathrm{O} \mathrm{m}^{-2} \mathrm{~s}^{-1}\right)$ with statistical differences to all other treatments. In general, 'Negreta' and Smeralda varieties presented better results than those of the control in most of the treatments and measurements. Similar results in the second year, with Smeralda 15 having the highest values in the first two measurements (2.65 and $2.95 \mathrm{mmol} \mathrm{H}_{2} \mathrm{O} \mathrm{m}^{-2} \mathrm{~s}^{-1}$, for 60 and 90 DAS) compared to 'Smeralda' 0 (1.64 and 1.65 mmol H $\mathrm{O} \mathrm{m}^{-2} \mathrm{~s}^{-1}$, for 60 and $\left.90 \mathrm{DAS}\right)$ while there were no significant differences with 'Negreta' $15(2.75 \mathrm{mmol}$ $\left.\mathrm{H}_{2} \mathrm{O} \mathrm{m}^{-2} \mathrm{~s}^{-1}\right)$ and 'Smeralda' $30\left(2.89 \mathrm{mmol} \mathrm{H}_{2} \mathrm{O} \mathrm{m}^{-2} \mathrm{~s}^{-1}\right)$ in the second measurement. S'uper Aquadulce' 15 just like the first year presented the higher value in the last measurement $\left(3.71 \mathrm{mmol} \mathrm{H}_{2} \mathrm{O} \mathrm{m}^{-2} s^{-1}\right)$ with statistical differences to all other treatments. Overall, magnetic field treatment of 15 minutes duration, gave higher values than the control treatment in the transpiration rate of the second year with statistically significant differences, in all varieties, in the three measurements (Table 2).

For stomatal conductance on the other hand, in the first year only the first measurement showed statistically significant differences with 'Negreta' 15 treatment having higher results $\left(0.120 \mathrm{~mol} \mathrm{~m}^{-2} \mathrm{~s}^{-1}\right.$, for 60 DAS), with statistically significant differences to 'Negreta' $0\left(0.040 \mathrm{~mol} \mathrm{~m}^{-2} \mathrm{~s}^{-1}\right.$, for $\left.60 \mathrm{DAS}\right)$ and all the other treatments. In fact, for all varieties the magnetic field treatments of 30- and 45-minutes duration presented similar or significantly lower values than those of the control. In the second year however there have been statistically significant differences for 60 and 120 days after sowing. All three varieties presented the best results when exposed to 15 minutes of electromagnetic field. In particular, 'Smeralda' 15 gave the best value in the first measurement $\left(0.127 \mathrm{~mol} \mathrm{~m}^{-2} \mathrm{~s}^{-1}\right)$ with statistical differences to 'Smeralda' $0\left(0.060 \mathrm{~mol} \mathrm{~m}^{-2} \mathrm{~s}^{-1}\right)$ while 'Super Aqualdulce' 15 presented the best value in the third measurement $\left(0.130 \mathrm{~mol} \mathrm{~m}^{-2} \mathrm{~s}^{-1}\right)$ and statistical different to 'Super Aquadulce' $0\left(0.083 \mathrm{~mol} \mathrm{~m}^{-2} \mathrm{~s}^{-1}\right)$. In general, treatments of 45 minutes duration in all varieties gave similar or significantly lower values than those of the control in most of the measurements.

In this study, the main physiology measurements such as stomatal conductance, photosynthetic rate, and transpiration rate have been found to have statistically significant differences in broad beans when exposed to magnetic field treatment especially in the duration of 15 minutes of exposure. Magnetic field seed pretreatment had been found to enhance the physiology characteristics of maize plants, in particular, photosynthesis, transpiration rate and chlorophyll content had been improved even under drought stress conditions from magnetic field of 100 and $150 \mathrm{mT}$ and duration 5 and 10 minutes (Javed et al., 2011). Bilalis et al. (2013) found that physiology measurements were improved in the early stages of cotton cultivation when pulsed electromagnetic field was used as a pre-sowing seed treatment. Following up the PEMF study, Katsenios et al. (2016) found that the magnetic field pre-sowing treatment also improved the physiology characteristics of durum wheat and that an interaction between variety and magnetic exists. 
Table 2. Interaction of magnetic field and variety on photosynthetic rate $\left(\mu \mathrm{mol} \mathrm{CO} \mathrm{Cm}^{-2} \mathrm{~s}^{-1}\right)$, transpiration rate $\left(\mathrm{mmol} \mathrm{H}_{2} \mathrm{O} \mathrm{m}^{-2} \mathrm{~s}^{-1}\right)$ and stomatal conductance $\left(\mathrm{mol} \mathrm{m}^{-2} \mathrm{~s}^{-1}\right)$ at 60,90 and 120 days after sowing (DAS)

\begin{tabular}{|c|c|c|c|c|c|c|c|c|c|c|}
\hline & \multicolumn{3}{|c|}{ Photosynthetic rate } & \multicolumn{3}{|c|}{ Transpiration rate } & \multicolumn{3}{|c|}{ Stomatal conductance } \\
\hline & & $60 \mathrm{DAS}$ & $90 \mathrm{DAS}$ & $120 \mathrm{DAS}$ & $60 \mathrm{DAS}$ & $90 \mathrm{DAS}$ & 120 DAS & 60 DAS & 90 DAS & 120 DAS \\
\hline \multirow{12}{*}{$\begin{array}{l}\text { First } \\
\text { year }\end{array}$} & $\begin{array}{c}\text { Negreta } \\
0\end{array}$ & $10.31 \mathrm{D}$ & $12.23 \mathrm{C}$ & $\begin{array}{l}11.22 \\
\mathrm{CDE}\end{array}$ & $1.22 \mathrm{DE}$ & $2.23 \mathrm{DE}$ & $2.02 \mathrm{DE}$ & $\begin{array}{l}0.040 \\
\text { DEF }\end{array}$ & $0.097 \mathrm{~A}$ & $0.083 \mathrm{~A}$ \\
\hline & $\begin{array}{c}\text { Negreta } \\
15 \\
\end{array}$ & $13.90 \mathrm{~A}$ & $16.43 \mathrm{~A}$ & $13.86 \mathrm{AB}$ & $2.51 \mathrm{~A}$ & $3.39 \mathrm{~A}$ & $2.72 \mathrm{C}$ & $0.120 \mathrm{~A}$ & $0.143 \mathrm{~A}$ & $0.140 \mathrm{~A}$ \\
\hline & $\begin{array}{c}\text { Negreta } \\
30 \\
\end{array}$ & $10.8 \mathrm{CD}$ & $13.84 \mathrm{~B}$ & $\begin{array}{c}11.40 \\
\text { BCDE }\end{array}$ & $1.77 \mathrm{~B}$ & $2.49 \mathrm{CD}$ & $2.69 \mathrm{C}$ & $0.077 \mathrm{C}$ & $0.087 \mathrm{~A}$ & $0.077 \mathrm{~A}$ \\
\hline & $\begin{array}{c}\text { Negreta } \\
45 \\
\end{array}$ & $12.34 \mathrm{BC}$ & $9.19 \mathrm{DE}$ & $\begin{array}{l}9.49 \\
\text { DEF }\end{array}$ & $1.83 \mathrm{~B}$ & $2.38 \mathrm{CD}$ & $2.19 \mathrm{D}$ & $0.037 \mathrm{EF}$ & $0.107 \mathrm{~A}$ & $0.080 \mathrm{~A}$ \\
\hline & $\begin{array}{c}\text { Smeralda } \\
0 \\
\end{array}$ & $10.12 \mathrm{D}$ & $4.98 \mathrm{G}$ & $\begin{array}{c}11.48 \\
\text { BCDE }\end{array}$ & $\begin{array}{r}1.53 \\
\mathrm{BCD} \\
\end{array}$ & $1.67 \mathrm{G}$ & $1.35 \mathrm{~F}$ & $0.077 \mathrm{C}$ & $0.073 \mathrm{~A}$ & $0.057 \mathrm{~A}$ \\
\hline & $\begin{array}{c}\text { Smeralda } \\
15\end{array}$ & $12.43 \mathrm{~B}$ & $8.48 \mathrm{EF}$ & $12.86 \mathrm{BC}$ & $2.56 \mathrm{~A}$ & $3.45 \mathrm{~A}$ & $2.03 \mathrm{DE}$ & $0.100 \mathrm{~B}$ & $0.143 \mathrm{~A}$ & $0.070 \mathrm{~A}$ \\
\hline & $\begin{array}{c}\text { Smeralda } \\
30 \\
\end{array}$ & $12.22 \mathrm{BC}$ & $9.85 \mathrm{D}$ & $\begin{array}{l}11.27 \\
\mathrm{CDE}\end{array}$ & $1.65 \mathrm{~B}$ & $2.91 \mathrm{~B}$ & $1.93 \mathrm{E}$ & $0.060 \mathrm{CD}$ & $0.067 \mathrm{~A}$ & $0.083 \mathrm{~A}$ \\
\hline & $\begin{array}{c}\text { Smeralda } \\
45\end{array}$ & $12.02 \mathrm{BC}$ & $9.48 \mathrm{DE}$ & $\begin{array}{l}11.85 \\
\mathrm{BCD}\end{array}$ & $1.61 \mathrm{BC}$ & $2.63 \mathrm{BC}$ & $1.48 \mathrm{~F}$ & $0.070 \mathrm{C}$ & $0.110 \mathrm{~A}$ & $0.053 \mathrm{~A}$ \\
\hline & $\begin{array}{c}\text { Super } \\
\text { Aquadulce } \\
0 \\
\end{array}$ & $10.54 \mathrm{D}$ & $7.95 \mathrm{~F}$ & $\begin{array}{l}9.92 \\
\text { DEF }\end{array}$ & $\begin{array}{l}1.26 \\
\mathrm{CDE}\end{array}$ & $\begin{array}{l}1.94 \\
\text { EFG }\end{array}$ & $2.60 \mathrm{C}$ & $0.030 \mathrm{~F}$ & $0.087 \mathrm{~A}$ & $0.090 \mathrm{~A}$ \\
\hline & $\begin{array}{c}\text { Super } \\
\text { Aquadulce } \\
15 \\
\end{array}$ & $14.07 \mathrm{~A}$ & $10.24 \mathrm{D}$ & $15.44 \mathrm{~A}$ & $\begin{array}{l}1.52 \\
\mathrm{BCD}\end{array}$ & $\begin{array}{l}2.14 \\
\text { DEF }\end{array}$ & $3.85 \mathrm{~A}$ & $0.073 \mathrm{C}$ & $0.090 \mathrm{~A}$ & $0.097 \mathrm{~A}$ \\
\hline & $\begin{array}{c}\text { Super } \\
\text { Aquadulce } \\
30 \\
\end{array}$ & $9.77 \mathrm{D}$ & $9.24 \mathrm{DE}$ & $9.24 \mathrm{EF}$ & $1.16 \mathrm{E}$ & $1.81 \mathrm{FG}$ & $3.38 \mathrm{~B}$ & $\begin{array}{l}0.057 \\
\mathrm{CDE}\end{array}$ & $0.063 \mathrm{~A}$ & $0.083 \mathrm{~A}$ \\
\hline & $\begin{array}{c}\text { Super } \\
\text { Aquadulce } \\
45\end{array}$ & $9.69 \mathrm{D}$ & $5.17 \mathrm{G}$ & $8.20 \mathrm{~F}$ & $1.14 \mathrm{E}$ & $1.84 \mathrm{FG}$ & $2.64 \mathrm{C}$ & $\begin{array}{l}0.047 \\
\text { DEF }\end{array}$ & $0.067 \mathrm{~A}$ & $0.077 \mathrm{~A}$ \\
\hline \multirow{12}{*}{$\begin{array}{c}\text { Second } \\
\text { year }\end{array}$} & $\begin{array}{c}\text { Negreta } \\
0\end{array}$ & $7.31 \mathrm{a}$ & $12.23 \mathrm{c}$ & $10.48 \mathrm{c}$ & $1.72 \mathrm{~d}$ & $2.19 \mathrm{de}$ & $2.10 \mathrm{e}$ & $0.070 \mathrm{e}$ & $0.120 \mathrm{a}$ & $0.067 \mathrm{f}$ \\
\hline & $\begin{array}{c}\text { Negreta } \\
15\end{array}$ & $12.69 \mathrm{a}$ & $16.43 \mathrm{a}$ & $14.08 \mathrm{~b}$ & $2.27 \mathrm{~b}$ & $2.75 \mathrm{ab}$ & $2.64 c$ & $0.103 \mathrm{c}$ & $0.160 \mathrm{a}$ & $0.097 \mathrm{c}$ \\
\hline & $\begin{array}{c}\text { Negreta } \\
30\end{array}$ & $9.89 \mathrm{a}$ & $13.84 \mathrm{~b}$ & $7.16 \mathrm{e}$ & $2.09 \mathrm{c}$ & $2.43 \mathrm{~cd}$ & $2.65 c$ & $0.097 \mathrm{~cd}$ & $0.123 \mathrm{a}$ & $0.080 \mathrm{df}$ \\
\hline & $\begin{array}{c}\text { Negreta } \\
45\end{array}$ & $7.49 a$ & $9.19 \mathrm{de}$ & $8.28 \mathrm{~d}$ & $1.77 \mathrm{~d}$ & $2.28 \mathrm{cde}$ & $2.34 \mathrm{~d}$ & $0.053 \mathrm{f}$ & $0.113 \mathrm{a}$ & $0.070 \mathrm{ef}$ \\
\hline & $\begin{array}{c}\text { Smeralda } \\
0\end{array}$ & $8.78 \mathrm{a}$ & $4.98 \mathrm{~g}$ & $8.17 \mathrm{de}$ & $1.64 \mathrm{~d}$ & $1.65 \mathrm{~g}$ & $1.38 \mathrm{~g}$ & $0.060 \mathrm{ef}$ & $0.093 \mathrm{a}$ & $0.053 \mathrm{~g}$ \\
\hline & $\begin{array}{c}\text { Smeralda } \\
15\end{array}$ & $12.36 \mathrm{a}$ & $8.48 \mathrm{ef}$ & $10.60 \mathrm{c}$ & $2.65 \mathrm{a}$ & $2.95 \mathrm{a}$ & $2.13 \mathrm{e}$ & $0.127 \mathrm{a}$ & $0.150 \mathrm{a}$ & $0.083 \mathrm{~d}$ \\
\hline & $\begin{array}{c}\text { Smeralda } \\
30 \\
\end{array}$ & $8.72 \mathrm{a}$ & $9.85 \mathrm{~d}$ & $9.91 \mathrm{c}$ & $2.11 \mathrm{c}$ & $2.89 \mathrm{a}$ & $1.73 \mathrm{f}$ & $0.110 b c$ & $0.090 \mathrm{a}$ & $0.090 \mathrm{~cd}$ \\
\hline & $\begin{array}{c}\text { Smeralda } \\
45\end{array}$ & $8.37 \mathrm{a}$ & $9.48 \mathrm{de}$ & $7.60 \mathrm{de}$ & $2.03 \mathrm{c}$ & $2.52 b c$ & $1.60 \mathrm{f}$ & $0.120 \mathrm{ab}$ & $0.090 \mathrm{a}$ & $0.067 \mathrm{f}$ \\
\hline & $\begin{array}{c}\text { Super } \\
\text { Aquadulce } \\
0 \\
\end{array}$ & $5.86 \mathrm{a}$ & $7.95 \mathrm{f}$ & $10.58 \mathrm{c}$ & $1.26 \mathrm{e}$ & $2.05 \mathrm{eg}$ & $2.74 \mathrm{c}$ & $0.060 \mathrm{ef}$ & $0.087 \mathrm{a}$ & $0.083 \mathrm{~d}$ \\
\hline & $\begin{array}{c}\text { Super } \\
\text { Aquadulce } \\
15\end{array}$ & $10.53 \mathrm{a}$ & $10.24 \mathrm{~d}$ & $16.33 \mathrm{a}$ & $1.71 \mathrm{~d}$ & $2.20 \mathrm{de}$ & $3.71 \mathrm{a}$ & $0.087 \mathrm{~d}$ & $0.133 \mathrm{a}$ & $0.130 \mathrm{a}$ \\
\hline & $\begin{array}{c}\text { Super } \\
\text { Aquadulce } \\
30 \\
\end{array}$ & $6.40 \mathrm{a}$ & $9.24 \mathrm{de}$ & $13.72 \mathrm{~b}$ & $1.20 \mathrm{e}$ & $1.82 \mathrm{fg}$ & $3.18 \mathrm{~b}$ & $0.060 \mathrm{ef}$ & $0.073 \mathrm{a}$ & $0.113 \mathrm{~b}$ \\
\hline & $\begin{array}{c}\text { Super } \\
\text { Aquadulce } \\
45\end{array}$ & $4.80 \mathrm{a}$ & $5.17 \mathrm{~g}$ & $9.71 \mathrm{c}$ & $1.00 \mathrm{f}$ & $1.78 \mathrm{~g}$ & $2.43 \mathrm{~d}$ & $0.053 \mathrm{f}$ & $0.077 \mathrm{a}$ & $0.097 \mathrm{c}$ \\
\hline
\end{tabular}

For each measurement in first year, means followed by the same capital letter (A, B, C, D, E, F, G) did not differ significantly according to Duncan's multiple range test at $\mathrm{p}<0.05$. For each measurement in second year, means followed by the same lower-case letter $(\mathrm{a}, \mathrm{b}$, c, d, e, f, g) did not differ significantly according to Duncan's multiple range test at $\mathrm{p}<0.05$. 


\section{Dry weight and yield}

Dry weight $\left(\mathrm{g}\right.$ plant $\left.{ }^{-1}\right)$ was significantly affected by the treatments that were tested on broad beans for 80 and 110 days after sowing for the first year and in all three measurements for the second. In the first year, the highest dry weight value has been measured at 'Smeralda' 15 (14.39 g/plant) for 80 DAS with statistically significant differences compared to all other treatments. 'Smeralda' 30 (13.28 g plant $\left.{ }^{-1}\right)$, 'Negreta' 15 (13.14 g plant $\left.{ }^{-1}\right)$ and 'Smeralda' 45 (13.13 $\left.\mathrm{g} \mathrm{plant}^{-1}\right)$ followed, with statistically significant differences compared to the remaining treatments, for the second measurement. At the third measurement, 'Negreta' 15 (65.62 $\left.\mathrm{g} \mathrm{plant}^{-1}\right)$ and 'Smeralda' 15 (64.30 $\left.\mathrm{g} \mathrm{plant}^{-1}\right)$ values were statistically significant different compared to all other treatments. It is important to note that the treatment of 'Super Aquadulce' 15 ( $54.70 \mathrm{~g} \mathrm{plant}^{-1}$ ) even if it had lower dry weight than the other varieties, had the highest values compared to the control and the other magnetic field treatments of the same variety.

In the second year, the highest value of plant dry weight was measured in 'Smeralda' 15 treatment (4.06, 17.15 and $67.14 \mathrm{~g} \mathrm{plant}^{-1}$, for 50, 80 and 110 DAS respectively) in all three measurements with statistically significant differences compared to the 'Smeralda' 0 (3.38, 14.80 and 44.07 g plant $^{-1}$, for 50, 80 and 110 DAS respectively) and all the other treatments without exceptions. Overall, all the magnetic field treatments had once again better results than the control. In general, the exposure of broad bean seeds of the three varieties at magnetic field for 15 and 30 minutes, gave statistically significant higher values compared to the control treatment of each variety (Figure 5).

A very interesting result of this two-year experiment is the fact that although there was an influence of the exposure of magnetic field on the dry weight of the plants of the three varieties of broad beans, there was not a positive or a negative influence on the seed yield for both years (Table 1). This means that magnetic field enhanced the vegetative development of the broad beans, but it had no effect on the reproductive development. The results indicate that magnetic field can be used in the cases that the productive direction of the cultivation of broad beans is for livestock forage and silage, as the pre-sowing treatment of seeds had a positive effect on plant dry weight.

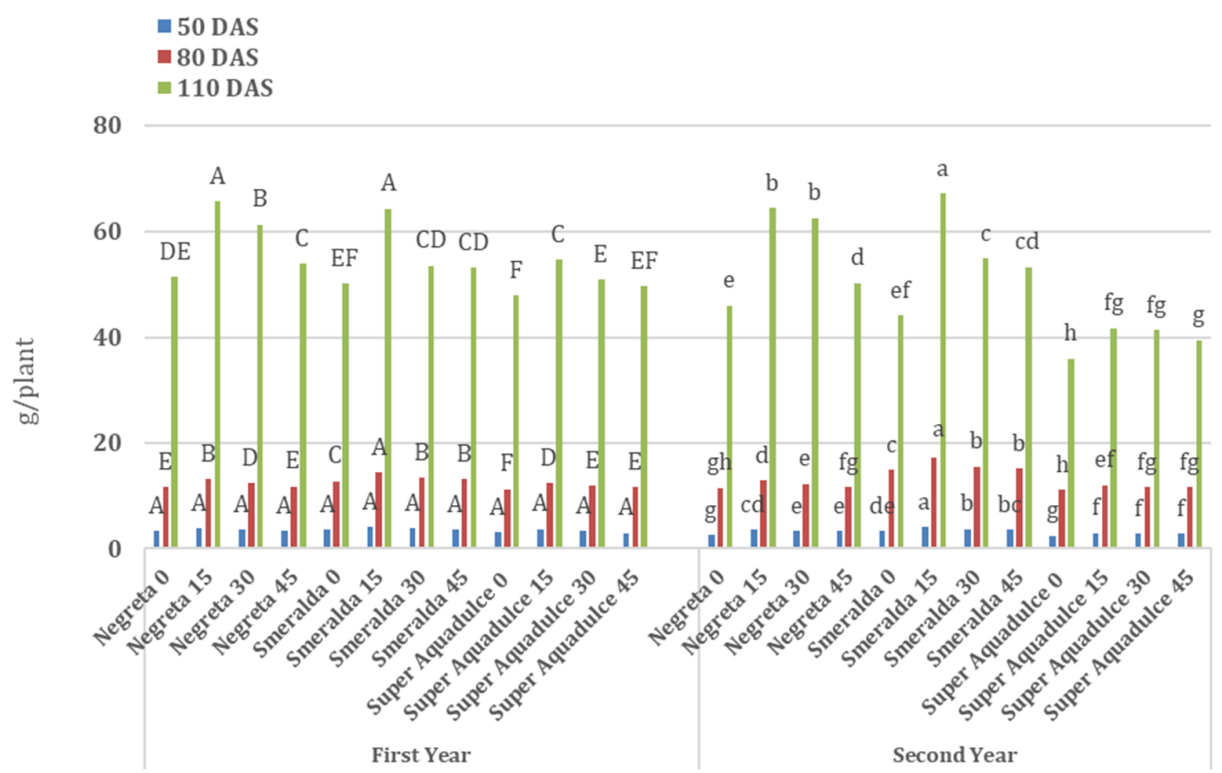

Figure 5. Broad beans Dry weight as affected by variety and magnetic field interaction at 50 days after sowing (DAS), 80 DAS and 110 DAS

For each measurement, means followed by the same capital letter (A, B, C, D, E, F, G) in first year and means followed by the same lower-case letter (a, b, c, d, e, f, g, h) in second year did not differ significantly according to Duncan's multiple range test at $\mathrm{p}<0.05$. 
In a tomato experiment, dry weight showed significantly higher values than the control, while there was also an increase of $27 \%$ by magnetic field treatment at the final yield compared to the control (De Souza et al., 2006). In 2008, Vashisth and Nagarajan evaluated how static magnetic field interferes with the early growth characteristics of chickpea as well as its germination. They found that chickpea seeds when exposed to static magnetic field present significant better results in case of germination, seedling length and dry weight than the control under certain combinations of magnetic field strength and duration. The same researchers some years later in another study exposed sunflower seeds to static magnetic field to find that it statistically affected positively dry weight and other growth parameters as well as yield (Vashisth and Nagarajan, 2010)

In a more recent study, Hussain et al. (2020) evaluated the effect of the magnetic field exposure of wheat seeds and found that besides a higher germination rate, the treated seeds also produced plants with higher plant growth characteristics and final yields than the untreated in various weather conditions.

Table 3. Results of multiple regression analysis of (15) measurements that have been conducted by using backward method of elimination in order to predict the dependent variable DW 110 DAS

\begin{tabular}{|c|c|c|c|c|}
\hline & Coefficient & Std. Error & $\mathrm{t}$ & $\mathrm{p}$ value \\
\hline & \multicolumn{4}{|c|}{ DW 110 DAS First year } \\
\hline (Constant) & -32.352 & 8.279 & -3.908 & .001 \\
\hline Dry weight 80 DAS & 6.854 & .856 & 8.008 & .000 \\
\hline Photosynthetic rate 60 DAS & -.432 & .202 & -2.145 & .041 \\
\hline Photosynthetic rate 90 DAS & .435 & .141 & 3.084 & .005 \\
\hline Transpiration rate $60 \mathrm{DAS}$ & 5.875 & .810 & 7.258 & .000 \\
\hline Germination percentage 10 DAS & -.764 & .221 & -3.461 & .002 \\
\hline Germination percentage 15 DAS & .307 & .149 & 2.066 & .049 \\
\hline Germination percentage 30 DAS & -.736 & .204 & -3.609 & .001 \\
\hline \multirow[t]{2}{*}{ Chlorophyll content 90 DAS } & .165 & .062 & 2.648 & .013 \\
\hline & \multicolumn{4}{|c|}{ DW 110 DAS Second year } \\
\hline (Constant) & -5.953 & 7.200 & -.827 & .416 \\
\hline Dry weight 50 DAS & 8.652 & 3.480 & 2.486 & .020 \\
\hline Leaf area 50 DAS & -.039 & .021 & -1.877 & .072 \\
\hline Leaf area $80 \mathrm{DAS}$ & .033 & .014 & 2.364 & .026 \\
\hline Photosynthetic rate 90 DAS & 1.100 & .380 & 2.896 & .008 \\
\hline Transpiration rate $60 \mathrm{DAS}$ & 15.044 & 3.590 & 4.191 & .000 \\
\hline Transpiration rate 90 DAS & -5.631 & 2.973 & -1.894 & .069 \\
\hline Germination percentage 15 DAS & -.456 & .170 & -2.681 & .013 \\
\hline Chlorophyll content 60 DAS & .804 & .258 & 3.114 & .004 \\
\hline Chlorophyll content 90 DAS & -.556 & .192 & -2.891 & .008 \\
\hline
\end{tabular}

According to the multiple regression analysis, for the first year, the value of DW 110 DAS was statistically significant affected from the measurements of Dry Weight (DW) 80 DAS, Photosynthetic Rate (PR) 60 and 90 DAS, Transpiration Rate (TR) 60 DAS, Germination percentage (GERM) 10, 15 and 30 DAS and Chlorophyll content (CHLOR) 90 DAS. The excluded variables were LA80, CHLOR60, DW50, TR90, SC90, LA50 and SC60. The selected model has Adjusted R-Squared: 0.943 , which means that 94.3\% of the variability of DW 110 is explained from the independent variables mentioned above.

For the first year the function of the model is:

$$
\begin{aligned}
\text { DW1 } 10= & -32.352+6.854 \times \text { DW80 }-0.432 \times \text { PR60 }+0.435 \times \text { PR90 }+5.875 \times \text { TR60 } \\
& -0.764 \times \text { GERM } 10+0.307 \times \text { GERM } 15-0.736 \times \text { GERM } 30+0.165 \times \text { CHLOR90 }
\end{aligned}
$$

For the second year, according to the multiple regression analysis, the value of DW 110 DAS was statistically significant affected from the measurements of Dry Weight (DW) 50 DAS, Leaf Area (LA) 50 and 80 DAS, Photosynthetic Rate (PR) 90 DAS, Transpiration Rate (TR) 60 and 90 DAS, Germination percentage (GERM) 15 DAS and Chlorophyll content (CHLOR) 60 and 90 DAS. The excluded variables 
were: DW80, PR60, SC90, GERM30, SC60 and GERM10. The selected model has Adjusted R-Squared: 0.900 , which means that $90.0 \%$ of the variability of DW 110 is explained from the independent variables mentioned above.

For the second year the function of the model is:

DW110 $=-5.953+8.652 \times$ DW50 $-0.039 \times$ LA50 $+0.033 \times$ LA80 $+1.1 \times$ PR90 + $15.044 \times$ TR60 $-5.631 \times$ TR90 $-0.456 \times$ GERM15 + $0.804 \times$ CHLOR60 $-0.556 \times$ CHLOR90

\section{Conclusions}

The use of pulsed electromagnetic field as a pre-sowing treatment on three varieties of broad bean seeds, increased germination percentage, leaf area, chlorophyll content, photosynthetic rate, transpiration rate, stomatal conductance and dry weight. The duration of exposure of 15 minutes, gave the highest values compared to the control treatments for the three varieties used. Treated seeds of broad beans had increased germination percentage, which means a better establishment of the cultivation. Moreover, the plants of the pulsed electromagnetic field treatments had higher values of chlorophyll content, which could explain the increased values of physiology measurements. A very interesting result is the fact that the exposure at pulsed electromagnetic field had a positive effect on the dry weight of the plants, while it had no effect (positive or negative) at the seed yield for both years. This means that magnetic field enhanced the vegetative development of the broad beans, but it did not affect the reproductive development. The results of this study highlight the importance of the productive direction of the cultivation. The use of magnetic field as a pre-sowing treatment that results in increased dry weight of broad beans is very important for livestock forage and silage production, while it has no effect for the seed production.

\section{Authors' Contributions}

Conceptualization: NK and AE; Data curation: NK and PS; Formal analysis: NK; PS; IK and AE; Investigation: NK; PS; IK and AE; Methodology: NK and AE; Project administration: NK, Software: NK; PS; IK and AE; Supervision: NK and AE; Writing - original draft: NK and PS; Writing - review and editing: NK; PS; IK and AE; All authors read and approved the final manuscript.

\section{Acknowledgements}

This research received no specific grant from any funding agency in the public, commercial, or not-forprofit sectors.

\section{Conflict of Interests}

The authors declare that there are no conflicts of interest related to this article. 


\section{References}

Aguilar CH, Pacheco AD, Carballo AC, Orea AC, Ivanov R, Bonilla JLL, Montanez JPV (2009). Alternative magnetic field irradiation effects on three genotype maize seed field performance. Acta Agrophysica 14(1): 7-17. http://www.acta-agrophysica.org/Alternating-magnetic-field-irradiation-effects-on-three-genotype-maize-seedfield, 107313,0,2.html

Aksyonov SI, Bulychev AA, Grunina TYu, Goryachev SN, Turovetsky VB (2001). Effects of ELF-EMF treatment on wheat seeds at different stages of germination and possible mechanisms of their origin. Electromagnetic Biology and Medicine 20(2):231-253. https://doi.org/10.1081/JBC-100104146

Aladjadjiyan A, Ylieva T (2003). Influence of stationary magnetic field on the early stages of the development of tobacco seeds (Nicotiana tabacum L.). Journal of Central European Agriculture 4(2):131-138. https://jcea.agr.hr/en/issues/article/124

Aladjadjiyan A (2012). Physical factors for plant growth stimulation improve food quality. Food Production-Approaches, Challenges and Tasks 270. https://doi.org/10.5772/32039

Ashraf M, Foolad MR (2005). Pre-sowing seed treatment - A shotgun approach to improve germination, plant growth and crop yield under saline and non-saline conditions. Advances in Agronomy 88:223-271. https://doi.org/10.1016/S0065-2113(05)88006-X

Bhardwaj J, Anand A, Nagarajan S (2012). Biochemical and biophysical changes associated with magneto-priming in germinating cucumber seeds. Plant Physiology and Biochemistry 57:67-73. https://doi.org/10.1016/j.plaphy.2012.05.008

Bilalis D, Katsenios N, Efthimiadou A, Karkanis A (2012a). Pulsed electromagnetic fields effect in oregano rooting and vegetative propagation: A potential new organic method. Acta Agriculturae Scandinavica, Section B - Soil \& Plant Science 62:94-99. https://doi.org/10.1080/09064710.2011.570374

Bilalis D, Katsenios N, Efthimiadou A, Karkanis A (2012b). Investigation of pulsed electromagnetic field as a novel organic pre-sowing method on germination and initial growth stages of cotton. Electromagnetic Biology and Medicine 31(2):143-150. https://doi.org/10.3109/15368378.2011.624660

Bilalis D, Katsenios N, Efthimiadou A, Karkanis A, Khah ME, Mitsis T (2013). Magnetic field pre-sowing treatment as an organic friendly technique to promote plant growth and chemical elements accumulation in early stages of cotton. Australian Journal of Crop Science 7(1):46-50. http://hdl.handle.net/11615/26295

Carbonell MV, Martínez E, Amaya JM (2000). Stimulation of germination in rice (Oryza sativa L.) by a static magnetic field. Electromagnetic Biology and Medicine 19 (1):121-128. https://doi.org/10.1081/JBC-100100303

De Souza A, García D, Sueiro L, Gilart F, Porras E, Licea L (2006). Pre-sowing magnetic treatments of tomato seeds increase the growth and yield of plants. Bioelectromagnetic s27(4):247-257. https://doi.org/10.1002/bem.20206

Es'kov EK, Rodionov Yu A (2010). Initial growth processes in seeds in magnetic fields, strengthened or weakened in relation to the geomagnetic field. Biology Bulletin 37:49-55. https://doi.org/10.1134/S1062359010010073

Flórez M, Carbonell MV, Martínez E (2007). Exposure of maize seeds to stationary magnetic fields: Effects on germination and early growth. Environmental and Experimental Botany 59(1):68-75. https://doi.org/10.1016/j.envexpbot.2005.10.006

Hussain MS, Dastgeer G, Afzal AM, Hussain S, Kanwar RR (2020). Eco-friendly magnetic field treatment to enhance wheat yield and seed germination growth. Environmental Nanotechnology, Monitoring \& Management 14:100299. https://doi.org/10.1016/j.enmm.2020.100299

Javed N, Ashraf M, Akram Nudrat A, Al-Qurainy F (2011). Alleviation of adverse effects of drought stress on growth and some potential physiological attributes in maize (Zea mays L.) by seed electromagnetic treatment. Photochemistry and Photobiology 87:1354-1362. https://doi.org/10.1111/j.1751-1097.2011.00990.x

Katsenios N, Bilalis D, Efthimiadou A, Aivalakis G, Nikolopoulou A, Karkanis A, Travlos I (2016). Role of pulsed electromagnetic field on enzyme activity, germination, plant growth and yield of durum wheat. Biocatalysis and Agricultural Biotechnology 6:152-158. https://doi.org/10.1016/j.bcab.2016.03.010

Leelapriya T, Dhilip KS, Sanker Narayan PV (2003). Effect of weak sinusoidal magnetic field on germination and yield of cotton (Gossypium spp.). Electromagnetic Biology and Medicine 22:117-125. https://doi.org/10.1081/JBC120024621

Lichtenthaler HK, Wellburn AR (1983). Determinations of total carotenoids and Chlorophylls a and b of leaf extracts in different solvents. Biochemical Society Transactions11:591-592. https://doi.org/10.1042/bst0110591 
Martínez E, Carbonell MV, Flórez M, Amaya JM, Maqueda R (2009). Germination of tomato seeds (Lycopersicon esculentum L.) under magnetic field. International Agrophysics 23:45-49. http://www.internationalagrophysics.org/Germination-of-tomato-seeds-Lycopersicon-esculentum-L-under-magneticfield, 106414,0,2.html

Muszyński S, Gagoś M, Pietruszewski S (2009) Short-term pre-germination exposure to ELF magnetic fields does not Influence seedling growth in durum wheat (Triticum durum). Polish Journal of Environmental Studies 18(6):1065-1072. http://www.pjoes.com/Short-Term-Pre-Germination-Exposure-to-ELF-r-nMagnetic-FieldDoes-Not-Influence-Seedling,88329,0,2.html

Novitsky YuI, Novitskaya GV, Kocheshkova TK, Nechiporenko GA, Dobrovol'skii MV (2001). Growth of green onions in a weak permanent magnetic field. Russian Journal of Plant Physiology 48(6):709-716. https://doi.org/10.1023/A:1012547004545

Podlesny J, Pietruszewski S, Podlesna A (2004). Efficiency of the magnetic treatment of broad bean seeds cultivated under experimental plot conditions. International Agrophysics 18:65-71. http://www.internationalagrophysics.org/Efficiency-of-the-magnetic-treatment-of-broad-bean-seeds-ncultivated-underexperimental, 106680,0,2.html

Răcuciu M, Creangă D, Horga I (2008). Plant growth under static magnetic field influence. Romanian Journal of Physics 53:331-336. http://www.nipne.ro/rjp/2008_53_1-2/0353_0360.pdf

Radhakrishnan R, Ranjitha Kumari B (2012). Pulsed magnetic field: A contemporary approach offers to enhance plant growth and yield of soybean. Plant Physiology and Biochemistry 59:139-177. https://doi.org/10.1016/j.plaphy.2011.10.017

Radhakrishnan R, Ranjitha Kumari B (2013). Influence of pulsed magnetic field on soybean (Glycine max L.) seed germinate seedling growth and soil microbial population. Indian Journal of Biochemistry and Biophysics 50(4):312-317. https://pubmed.ncbi.nlm.nih.gov/24772951/

Shine M, Guruprasad K, Anand A (2011). Enhancement of germination, growth, and photosynthesis in soybean by pretreatment of seeds with magnetic field. Bioelectromagnetics 32:474-484. https://doi.org/10.1002/bem.20656

Soja G, Kunsch B, Gerzabek M, Reichenauer T, Soja A-M,Bolhàr-Nordenkampf HR (2003). Growth and yield of winter wheat (Triticum aestivum L.) and corn (Zea mays L.) near a high voltage transmission line. Bioelectromagnetics 24:91-102. https://doi.org/10.1002/bem.10069

Vashisth A, Nagarajan S (2008). Exposure of seeds to static magnetic field enhances germination and early growth characteristics in chickpea (Cicer arietinum L.). Bioelectromagnetics 29(7):571-578. https://doi.org/10.1002/bem.20426

Vashisth A, Nagarajan S (2010). Effect on germination and early growth characteristics in sunflower (Helianthus annuus) seeds exposed to static magnetic field. Journal of Plant Physiology 167(2):149-156. https://doi.org/10.1016/j.jplph.2009.08.011

Vashisth A, Joshi DK (2017). Growth characteristics of maize seeds exposed to magnetic field. Bioelectromagnetics 38(2):151-157. https://doi.org/10.1002/bem.22023

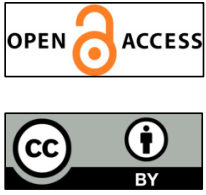

The journal offers free, immediate, and unrestricted access to peer-reviewed research and scholarly work. Users are allowed to read, download, copy, distribute, print, search, or link to the full texts of the articles, or use them for any other lawful purpose, without asking prior permission from the publisher or the author.

License - Articles published in Notulae Botanicae Horti Agrobotanici Cluj-Napoca are Open-Access, distributed under the terms and conditions of the Creative Commons Attribution (CC BY 4.0) License. (c) Articles by the authors; UASVM, Cluj-Napoca, Romania. The journal allows the author(s) to hold the copyright/to retain publishing rights without restriction. 